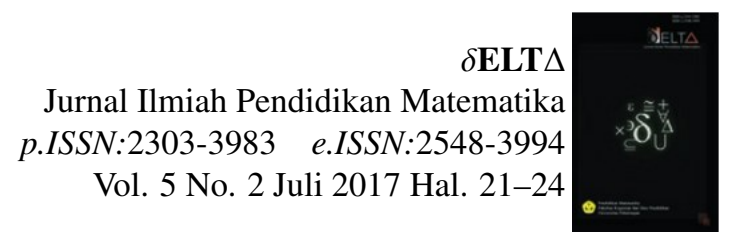

\title{
DESKRIPSI TIPE KESALAHAN MAHASISWA DALAM UAS MATA KULIAH STATISTIKA PENELITIAN PENDIDIKAN
}

\author{
Syita Fatih Adna ${ }^{a}$ \\ ${ }^{a}$ Universitas Pekalongan, syita.fatih@gmail.com
}

\begin{abstract}
This research was conducted at the University of Pekalongan Mathematics Education Program. The subject of the research was the students of the sixth semester B who followed the Education Research Statistics course of the academic year 2016/2017. The purpose of the research was to describe the type of student errors in the UAS Education Research Statistics course. The student error type consisted of concept errors, miscalculations, and procedural errors. In analyzing student error was associated with the competence of the achievement of the course which was then derived in some indicators of the achievement of the course. In addition, it was also associated with the level of difficulty of questions and levels of cognitive domain. Based on the results of student error analysis in the UAS course of Statistics Research, most students made mistakes on the concept. The student error was dominant on the problem with the cognitive level of $C_{3}$ (applying) and $C_{4}$ (analyze). The error in the regression discussion lied in making the regression equation. While in the discussion of two-way variance analysis, the student's fault lied in making the research conclusions.
\end{abstract}

Keywords: description, students error, Education Research Statistics

\section{Pendahuluan}

Statistika Penelitian Pendidikan merupakan salah satu mata kuliah syarat agar mahasiswa dapat mengambil Skripsi. Hal ini tertuang dalam Borang Program Studi Matematika tahun 2015. Sehingga, mahasiswa yang belum lulus dalam mata kuliah Statistika Penelitian Pendidikan tidak diperbolehkan untuk mengambil Skripsi. Mata Kuliah yang hanya 3 sks ini, banyak berkaitan dengan teknik-teknik analisis data yang digunakan dalam penelitian eksperimen. Teknik analisis data dalam penelitian eksperimen yang dibahas antara lain, uji hipotesis tentang mean, uji hipotesis tentang variansi, uji hipotesis tentang proporsi, analisis variansi satu jalan dan dua jalan beserta uji lanjut pasca anava, regresi, dan korelasi. Teknik-teknik tersebut berkaitan dengan pengolahan data Skripsi apabila jenis penelitiannya adalah penelitian eksperimen.

Standar kompetensi dari mata kuliah Statistika Penelitian Pendidikan adalah mahasiswa mampu membuat kesimpulan dari uji hipotesis, baik uji hipotesis tentang mean, uji hipotesis tentang variansi, uji hipotesis tentang proporsi, analisis variansi, regresi, maupun korelasi. Pembahasan materi kuliah untuk tengah semester meliputi uji hipotesis tentang mean, uji hipotesis tentang variansi, uji hipotesis tentang proporsi, dan analisis variansi satu jalan. Sedangkan materi kuliah analisis variansi dua jalan, regresi, dan korelasi dibahas setelah tengah semester. Namun, pada akhirnya diharapkan mahasiswa mampu menganalisis dan membuat kesimpulan dari uji hipotesis yang dilakukan.

Berdasarkan data dokumentasi nilai rerata ujian tengah semester mata kuliah Statistika Penelitian Pendidikan mencapai 65. Data ini diambil dari mahasiswa yang mengikuti mata kuliah Statistika Penelitian Pendidikan tahun ajaran 2016/2017 semester genap. Sedangkan nilai rerata ujian akhir semester tidak melebihi 60. Tentu saja hal ini menarik untuk diteliti, apa yang membuat nilai ujian akhir semester mahasiswa menurun dan dimana letak kesalahan mahasiswa dalam menjawab soal ujian akhir semester. Dengan mengetahui kesalahan-kesalahan mahasiswa dalam menjawab soal ujian akhir semester, dosen memperoleh gambaran keadaan mahasiswa untuk perbaikan kualitas pengajaran di tahun berikutnya. Kesalahan mahasiswa mengindikasikan bahwa kompetensi perkuliahan tidak tercapai.

Untuk materi perkuliahan setelah tengah semester memiliki beberapa kompetensi yang harus dicapai, antara lain mahasiswa dapat : 1) menganalisis analisis variansi dua jalan, 2) menyimpulkan uji analisis variansi dua jalan, 3) menyimpulkan uji regresi, 4) menganalisis uji korelasi. Soal ujian akhir semester genap tahun ajaran 2016/2017 yang mencakup empat kompetensi lulusan di atas terdiri dari 20 butir soal. Dari soal tersebut dianalisis untuk memperoleh deskripsi bagaimana kesalahan mahasiswa dalam menjawab soal serta bagian kompetensi manakah yang paling banyak kesalahan yang dibuat mahasiswa. Kesalahan mahasiswa dalam menjawab soal dikhawatirkan berakibat dalam penyusunan Skripsi. Berdasarkan pengamatan, beberapa mahasiswa yang telah menempuh Skripsi, 
kesalahan dalam mengolah data, kesalahan dalam menganalisis hingga dalam menyimpulkan uji hipotesisnya, dikarenakan ketidakpahaman mahasiswa saat menempuh mata kuliah Statistika Penelitian Pendidikan. Namun, mahasiswa tidak pernah bertanya mengenai ketidakpahaman dalam materi perkuliahan. Sebenarnya mahasiswa masih bingung, teknik analisis data mana yang akan digunakan dan kenapa menggunakan teknik analisis data tersebut, serta bagaimana mengolah data menggunakan teknik analisis data tersebut. Setiap teknik analisis data tentunya memiliki tujuan dan syarat penelitian tersendiri, sehingga mahasiswa tidak asal dalam memilih teknik analisis data. Hal ini sangat terlihat dari hasil ujian akhir semester yang sebagian besar tidak memuaskan.

Menurut (4), kesalahan siswa dalam mengerjakan soal matematika antara lain: 1) Kesalahan dalam membuat pemodelan matematika, 2) Kesalahan konsep, yaitu kesalahan dalam memahami konsep matematika, 3) Kesalahan strategi, yaitu kesalahan yang terjadi karena siswa memilih cara mengerjakan yang tidak tepat, 4) Kesalahan sistematik, yaitu kesalahan yang berkenaan dengan pemilihan yang salah atas teknik ekstrapolasi, 5) Kesalahan tanda, yaitu kesalahan dalam memberikan atau menulis tanda atau notasi matematika, 6) Kesalahan hitung, yaitu kesalahan dalam melakukan operasi matematika. Sedangkan menurut (5), kesalahan yang dilakukan siswa dalam mengerjakan soal matematika dibagi menjadi 3, yaitu; 1) Kesalahan konsep, dalam hal ini termasuk kesalahan dalam memahami soal, 2) Kesalahan perhitungan, 3) Kesalahan prosedur. Penelitian ini mengacu pada jenis kesalahan siswa menurut Endang Sulistyowati. Namun, dalam penelitian ini juga akan dibahas lebih terperinci mengapa bisa terjadi kesalahan tersebut.

\section{Metodologi Penelitian}

Penelitian ini merupakan penelitian deskriptif kuantitatif. Penelitian dilakukan di Universitas Pekalongan dengan subyek penelitiannya adalah mahasiswa semester VI B tahun ajaran 2016/2017 sebanyak 35 mahasiswa. Metode pengumpulan data dalam penelitian ini adalah metode tes dan metode wawancara. Soal tes dibuat dalam bentuk pilihan ganda sebanyak 20 butir dengan lima alternatif jawaban. Meskipun soal tes dalam bentuk pilihan ganda, namun mahasiswa diwajibkan untuk memberi alasan ataupun cara dalam memilih pilihan jawaban tersebut. Pemberian skor pada tes adalah skor satu jika benar dan skor nol jika salah. Mahasiswa dianggap menjawab benar apabila pilihan jawaban benar dan alasan yang diungkapkan tepat. Soal tes mencakup materi anava dua jalan, regresi, dan korelasi. Rincian soal tes, 12 butir mengenai analisis variansi dua jalan beserta uji lanjut analisis variansi dua jalan, 8 butir mengenai regresi dan korelasi. Waktu yang diberikan kepada mahasiswa untuk mengerjakan soal tersebut 75 menit. Hasil tes kemudian dianalisis kesalahan mahasiswa dalam menjawab soal. Dalam menganalisis kesalahan mahasiswa dalam menjawab soal dikaitkan dengan kompetensi capaian mata kuliah yang kemudian diturunkan dalam beberapa indikator capaian mata kuliah. Indikator capaian mata kuliah dapat dijabarkan sebagai berikut:

1. Menerapkan teknik analisis data anava dua jalan dalam penelitian

2. Menentukan prasyarat uji anava dua jalan

3. Mengolah data uji anava dua jalan

4. Membaca F tabel

5. Membuat kesimpulan berdasarkan hasil statistik uji

6. Mengolah data uji lanjut pasca anava

7. Membuat kesimpulan hasil uji lanjut pasca anava

8. Menerapkan teknik analisis data regresi dalam penelitian

9. Menentukan persamaan regresi

10. Memprediksi nilai amatan y

11. Menerapkan teknik analisis data korelasi

12. Menghitung koefisien korelasi

Selain mengacu pada indikator capaian mata kuliah, dalam menganalisis kesalahan mahasiswa juga memperhatikan tingkat kesukaran butir soal. Menurut (1) tingkat kesukaran yang dianggap baik bila berkisar 0,5. Sebagai patokan dapat digunakan tabel sebagai berikut:

Tabel 1. Kriteria Tingkat Kesukaran

\begin{tabular}{cc}
\hline Kriteria & nilai p \\
\hline sukar & $0.00-0.25$ \\
sedang & $0.26-0.75$ \\
mudah & $0.76-1.00$ \\
\hline
\end{tabular}

Sedangkan metode wawancara dilakukan dengan dosen pengampu mata kuliah Statistika Penelitian Pendidikan tahun ajaran 2016/2017. Metode ini digunakan untuk memperoleh data keadaan mahasiswa saat mengikuti perkuliahan. 


\section{Hasil dan Pembahasan}

Soal tes ujian akhir semester mata kuliah Statistika Penelitian Pendidikan disusun berdasarkan tingkatan ranah kognitif. Taksonomi kognitif untuk mempermudah proses penyusunan bank soal sehingga memiliki tujuan pembelajaran yang sama ((2)). Tingkatan ranah kognitif berdasarkan revisi yang dilakukan oleh Kratwohl dan Anderson meliputi mengingat, memahami, mengaplikasikan, menganalisis, mengevaluasi, dan mencipta ((3)). Artikel ini hanya akan menganalisis soal UAS Statistika Penelitian yang berada pada tingkatan memahami hingga mengevaluasi untuk materi analisis variansi dua jalur dan materi analisis korelasional. Karena beberapa soal mewakili indikator dan tingkatan kognitif yang sama, maka tidak semua soal dianalisis, melainkan hanya soal-soal tertentu yang dianggap mewakili.

\subsection{Hasil untuk Materi Analisis Variansi}

Untuk menilai pemahaman mahasiswa mengenai anava dua jalur maka diberikan Soal 1 .

Soal 1. Penelitian yang memerlukan analisis variansi dua jalan sebagai teknik analisis data adalah ....

a. Seorang guru ingin melihat apakah siswa dengan gaya belajar visual, auditori, dan kinestetik memiliki prestasi belajar matematika yang berbeda.

b. Seorang guru ingin memprediksi nilai ujian akhir matematika siswa dengan menggunakan nilai kemampuan pemecahan masalah, kemampuan berpikir kritis, dan kemampuan pemahaman konsep siswa.

c. Seorang guru ingin melihat apakah semakin tinggi kemampuan komunikasi matematis siswa maka semakin tinggi pula kemampuan pemecahan masalahnya.

d. Seorang guru ingin melihat apakah gaya belajar siswa (visual, auditori, dan kinestetik) dan metode mengajar (ceramah dan diskusi) berpengaruh terhadap prestasi belajar siswa.

e. Setidaknya terdapat 2 kasus (dari opsi $a, b, c, d$ ) yang perlu menggunakan anava dua jalan.

Menurut taksonomi Bloom Soal 1 merupakan ranah kognitif $C_{2}$ yaitu memahami. Mahasiswa diuji sejauh mana kepahaman dalam mengkategorikan jenis penelitian yang memerlukan teknik analisis data anava dua jalan. Dari 33 mahasiswa, hanya 7 mahasiswa yang mampu menjawab benar yaitu pilihan D beserta alasan yang benar. Dua puluh empat lainnya benar menjawab D namun, tidak bisa memberikan alasannya, atau dengan kata lain hanya menebak saja. Sedangkan empat lainnya menjawab pilihan E, yang menganggap bahwa pilihan A dan D juga benar. Padahal pilihan A merupakan penelitian yang menggunakan teknik analisis data anava satu jalan. Sehingga terlihat bahwa $80 \%$ mahasiswa masih bingung dalam mengkategorikan jenis penelitian yang memerlukan teknik analisis data anava dua jalan. Untuk kompetensi dasar menerapkan teknik analisis data anava dua jalan dalam penelitian mahasiswa sebagian besar belum menguasai. Beberapa mahasiswa masih menganggap bahwa penggunaan untuk penelitian anava satu jalan sama dengan anava dua jalan. Kesalahan mahasiswa untuk Soal 1 ini merupakan kesalahan konsep.

Berikutnya dibahas mengenai soal yang menguji kompetensi dasar mengolah data uji anava dua jalan. Untuk itu diberikan Soal 2

Soal 2. Suatu analisis variansi dua jalan dengan sel yang sama melibatkan variabel bebas $A$ dan variabel bebas B. Jika variabel A memiliki 4 kategori dan variabel B memiliki 5 kategori dan banyak data di masing-masing sel adalah 5, maka derajat kebebasan untuk faktor interaksi $(A B)$ dan faktor galat pada tabel rangkuman anava berturut-turut adalah ....

a. 19 dan 100

b. 12 dan 80

c. 12 dan 100

d. 19 dan 80

e. 20 dan 100

Pada Soal 2 mahasiswa diminta untuk menghitung derajat kebebasan faktor interaksi dan faktor galat. Menurut tingkatan kognitif soal ini merupakan tingkatan $C_{3}$ (aplikasi). Mahasiswa hanya menggunakan rumus dalam menghitung soal. Soal 2 ternyata memiliki tingkat kesukaran 0,34 yang termasuk kategori soal sedang. Padahal soal jenis ini tidak memerlukan logika yang lebih. Namun hanya 13 mahasiswa yang mampu menjawab benar beserta alasannya. Kesalahan yang dilakukan mahasiswa lainnya adalah 11 mahasiswa menjawab benar tanpa alasan atau hanya menebak saja, 2 mahasiswa tidak menjawab soal, dan 7 mahasiswa lainnya salah keduanya. Mahasiswa yang salah keduanya menggunakan rumus yang salah. Mereka hanya mengkalikan banyaknya kategori A dengan banyaknya kategori B untuk menghitung derajat kebebasan faktor interaksi (AB) sehingga diperoleh hasil 20. Kesalahan yang juga dilakukan mahasiswa untuk menghitung derajat kebebasan faktor galat adalah dengan mengkalikan banyaknya kategori A, banyaknya kategori B, dan banyaknya masing-masing sel sehingga diperoleh hasil 100. Kesalahan mahasiswa dalam menjawab Soal 2 merupakan kesalahan konsep. 
Masih dalam soal dengan kompetensi dasar mengolah data uji anava dua jalan, namun yang dihitung adalah F hitung dan membaca $\mathrm{F}$ tabel. Dalam hal ini tidak hanya kognitif saja yang diuji tetapi juga psikomotor yaitu keterampilan dalam membaca tabel F. Menurut tingkatan kognitif, Soal 3 termasuk $C_{3}$ (aplikasi) karena hanya menggunakan rumus tanpa membuktikan rumus tersebut.

Soal 3. Seorang guru melakukan penelitian untuk melihat apakah metode mengajar baru memberikan efek terhadap nilai matematika ditinjau dari jenis kelamin siswa. Nilai tes matematika dari 2 kelas yang diajar dengan metode baru dan metode lama berdasarkan jenis kelamin dapat dilihat pada tabel berikut:

\begin{tabular}{|c|c|c|}
\hline & \multicolumn{2}{|c|}{ Metode Mengajar } \\
\hline Jenis Kelamin & Lama & Baru \\
\hline Laki-Laki & 64 & 38 \\
& 75 & 53 \\
& 60 & 33 \\
& 69 & 46 \\
& 42 & 38 \\
\hline Perempuan & 42 & 25 \\
& 55 & 23 \\
& 50 & 32 \\
& 56 & 28 \\
& 51 & 43 \\
\hline
\end{tabular}

Sedangkan tabel rangkuman hasil anava adalah sebagai berikut:

\begin{tabular}{|c|c|c|c|c|c|}
\hline Sumber & Jumlah Kuadrat & $d k$ & Rataan Kuadrat & Fhitung & Ftabel \\
\hline Jenis Kelamin & 994,05 & & & & \\
Metode Mengajar & 2714,5 & & & & \\
Interaksi & 36,45 & & & & \\
Galat & 756 & & & & \\
\hline Total & 4501 & & & & \\
\hline
\end{tabular}

Nilai Fhitung dan Ftabel untuk baris Jenis Kelamin dengan $\alpha=0.05$ berturut-turut adalah ....

a. 0,771 dan 4,49

b. 21,04 dan 4,49

c. 57,45 dan 4,49

d. 21,04 dan 57,45

e. 57,45 dan 21,04

Soal 3 memiliki tingkat kesukaran 0,51 atau tergolong kesukaran yang sedang. Soal untuk jenis di atas mampu dijawab benar beserta alasannya sebanyak 17 mahasiswa. Sisanya salah dalam menghitung nilai $\mathrm{F}$ hitung dan 4 mahasiswa salah dalam membaca F tabel. Kesalahan dalam menghitung F hitung dikarenakan mahasiswa salah dalam menghitung RKG. Sedangkan mahasiswa yang salah dalam membaca F tabel dikarenakan derajat kebebasan dalam membaca tabel terbalik antara derajat kebebasan pembilang dan penyebut. Untuk soal no 5 sebagian besar mahasiswa melakukan kesalahan perhitungan.

Selanjutnya, mahasiswa diminta untuk menyimpulkan hasil uji anava dua jalan. Melalui hasil rangkuman anava dua jalan, mahasiswa diminta untuk membuat kesimpulan penelitian. Namun, sebelumnya, mahasiswa diharuskan untuk mengisi tabel rangkuman anava terlebih dahulu. Untuk bagian pengisian tabel, mahasiswa dituntut untuk mengingat konsep rataan kuadrat. Oleh sebab itu, soal ini juga termasuk kategori $C_{1}$. Akan tetapi, bagian tersebut tidak dibahas pada artikel ini. Soal yang diberikan adalah Soal 4

Soal 4. Seorang guru melakukan penelitian untuk melihat apakah metode mengajar baru memberikan efek terhadap nilai matematika ditinjau dari jenis kelamin siswa. Nilai tes matematika dari 2 kelas yang diajar dengan metode baru dan metode lama berdasarkan jenis kelamin dapat dilihat pada tabel berikut:

\begin{tabular}{|c|c|c|}
\hline & \multicolumn{2}{|c|}{ Metode Mengajar } \\
\hline Jenis Kelamin & Lama & Baru \\
\hline Laki-Laki & 64 & 38 \\
& 75 & 53 \\
& 60 & 33 \\
& 69 & 46 \\
& 42 & 38 \\
\hline Perempuan & 42 & 25 \\
& 55 & 23 \\
& 50 & 32 \\
& 56 & 28 \\
& 51 & 43 \\
\hline
\end{tabular}


Sedangkan tabel rangkuman hasil anava adalah sebagai berikut:

\begin{tabular}{|c|c|c|c|c|c|}
\hline Sumber & Jumlah Kuadrat & $d k$ & Rataan Kuadrat & Fhitung & Ftabel \\
\hline Jenis Kelamin & 994,05 & & & & \\
Metode Mengajar & 2714,5 & & & & \\
Interaksi & 36,45 & & & & \\
Galat & 756 & & & & \\
\hline Total & 4501 & & & & \\
\hline
\end{tabular}

Pernyataan berikut merupakan kesimpulan yang tepat untuk bacaan di atas, kecuali ....

a. Metode mengajar berpengaruh terhadap nilai matematika siswa.

b. Jenis kelamin berpengaruh terhadap nilai matematika siswa.

c. Terdapat perbedaan rata-rata antara siswa laki-laki dan perempuan.

d. Kombinasi antara jenis kelamin dan metode mengajar memberikan perbedaan pengaruh terhadap nilai matematika siswa.

e. Tidak terdapat interaksi antara variabel jenis kelamin dan metode mengajar.

Soal 4 termasuk dalam tingkatan kognitif $C_{4}$ (analisis). Mahasiswa perlu mempertimbangkan beberapa hal untuk membuat kesimpulan penelitian apakah hipotesis untuk jenis kelamin diterima atau tidak, apakah hipotesis untuk metode mengajar diterima atau tidak, dan apakah terdapat interaksi antara jenis kelamin dengan metode mengajar. Soal 4 memiliki tingkat kesukaran 0,09 dan soal tergolong sukar. Hanya 4 mahasiswa yang mampu menjawab benar dengan alasan yang benar. Sebanyak satu orang menjawab pilihan A, tiga orang memilih B, enam orang memilih $\mathrm{C}$, dan 8 orang memilih $\mathrm{D}$, sisanya tidak menjawab. Kesalahan yang dilakukan mahasiswa karena ketidaktelitian mahasiswa karena yang diminta justru yang bukan merupakan kesimpulan penelitian. Kesalahan yang lain dikarenakan kekeliruan dalam menghitung $\mathrm{F}$ hitung sehingga salah dalam membuat kesimpulan penelitian.

Selanjutnya, dibahas soal dengan kompetensi dasar menyimpulkan uji lanjut pasca anava, yaitu Soal 5 . Untuk mengerjakan Soal 5 mahasiswa diberikan bacaan tentang penelitian anava dua jalan. Dari bacaan tersebut telah diberikan data yang berkaitan dengan penelitian anava dua jalan. Pada Soal 5 mahasiswa diberikan suatu pernyataan hasil uji lanjut pasca anava dua jalan, kemudian mahasiswa diminta untuk membuat kesimpulannya.

Soal 5. Seorang guru melakukan penelitian untuk melihat apakah metode mengajar (STAD, TGT, TAI, Ceramah) memberikan efek terhadap nilai matematika ditinjau dari gaya belajar siswa. Tabel berikut menunjukkan rataan nilai matematika pada setiap grup.

\begin{tabular}{|c|c|c|c|c|}
\hline & \multicolumn{3}{|c|}{ Gaya Belajar } & \\
\hline Metode Mengajar & Visual & Auditori & Kinestetik & Rataan Marginal \\
\hline STAD & 6,2 & 6,4 & 6,7 & 6,5 \\
\hline TGT & 6,6 & 5,9 & 6,8 & 6,3 \\
\hline TAI & 7 & 6,8 & 6,7 & 6,8 \\
\hline Ceramah & 6,5 & 6,3 & 6,6 & 6,4 \\
\hline Rataan Marginal & 6,6 & 6,2 & 6,7 & \\
\hline
\end{tabular}

Jika hasil anava 2 jalan menunjukkan bahwa metode mengajar memberikan perbedaan nilai matematika, maka banyaknya pasangan hipotesis yang perlu diuji untuk melakukan uji komparasi ganda antar baris adalah ... pasang.
a. 4
b. 5
c. 6
d. 8
e. 12

Soal 5 termasuk dalam tingkatan ranah kognitif $C_{4}$ (analisis). Meskipun nampak mudah, tapi mahasiswa tidak sedikit yang salah membuat kesimpulan penelitiannya. Hanya $26 \%$ yang mampu menjawab pilihan dengan benar dan mampu memberikan argumen alasan memilih pilihan tersebut. Sebanyak $51 \%$ mahasiswa tidak bisa memberikan argumen alasan memilih pilihan B yang dianggap benar. Kesalahan yang dilakukan mahasiswa adalah salah dalam membandingkan rerata sel TAI-Visual dengan sel STAD-Visual yang menganggap bahwa metode STAD lebih baik daripada TAI, yang seharusnya TAI yang lebih baik daripada STAD. Dua mahasiswa lainnya memilih pilihan C dimana metode STAD sama baiknya dengan TAI. Hal ini dikarenakan yang dibandingkan adalah rerata sel TAI-Kinestetik dengan sel STAD- Kinestetik. Sebagian besar kesalahan yang dilakukan mahasiswa adalah kesalahan konsep, mereka tidak tahu apabila hipotesis antar sel ditolak maka rerata yang mana yang harus dibandingkan. 


\subsection{Hasil untuk Materi Analisis Korelasional}

Selanjutnya, diberikan soal untuk mengukur pemahaman mahasiswa mengenai kapan digunakan teknik regresi dan korelasi. Soal yang diberikan adalah Soal 6

Soal 6. Penelitian yang memerlukan regresi linear sebagai teknik analisis data adalah ....

a. Seorang guru ingin melihat apakah siswa dengan gaya belajar visual, auditori, dan kinestetik memiliki prestasi belajar matematika yang berbeda.

b. Seorang guru ingin memprediksi nilai ujian akhir matematika siswa dengan menggunakan nilai kemampuan pemecahan masalah, kemampuan berpikir kritis, dan kemampuan pemahaman konsep siswa.

c. Seorang guru ingin melihat apakah semakin tinggi kemampuan komunikasi matematis siswa maka semakin tinggi pula kemampuan pemecahan masalahnya.

d. Seorang guru ingin melihat apakah gaya belajar siswa (visual, auditori, dan kinestetik) dan metode mengajar (ceramah dan diskusi) berpengaruh terhadap prestasi belajar siswa.

e. Tidak ada kasus yang dapat menggunakan regresi linear.

Soal 6 seharusnya termasuk soal pemahaman $\left(C_{2}\right)$ yang mudah, karena mahasiswa hanya perlu mengkategorikan jenis-jenis penelitian yang menggunakan teknik analisis data regresi linear. Namun, berdasarkan hasil pekerjaan mahasiswa soal tersebut memiliki tingkat kesukaran sukar yaitu 0,11 . Hanya empat mahasiswa yang mampu menjelaskan dengan benar adanya sebab akibat, adanya prediksi, dan adanya hubungan X dan Y pada pilihan B. Sebagian besar mahasiswa memilih pilihan $\mathrm{C}$ dengan alasan bahwa pilihan $\mathrm{C}$ meneliti hubungan antara $\mathrm{X}$ dan Y. Mereka mengabaikan bahwa tidak semua penelitian yang meneliti hubungan X dan Y merupakan penelitian regresi. Penelitian regresi juga harus dapat digunakan untuk tujuan prediksi, sehingga yang paling benar adalah pilihan B. Kesalahan yang dilakukan mahasiswa ini adalah kesalahan konsep dikarenakan belum memahami tujuan dilakukannya penelitian, hanya meneliti hubungan X dan Y ataukah hingga mampu memprediksi Y apabila $\mathrm{X}$ diketahui, sehingga perlu ditekankan dalam perkuliahan mengenai tujuan penelitian agar mahasiswa tidak salah dalam menggunakan teknik analisis data yang akan digunakan.

Masih dalam tingkatan kognitif yang sama yaitu C2, soal berikutnya menguji kompetensi dasar menerapkan teknik analisis data korelasi dalam penelitian. Mahasiswa diminta untuk mengkategorikan penelitian yang termasuk dalam penelitian korelasi. Soal yang diberikan adalah Soal 7

Soal 7. Penelitian yang memerlukan perhitungan koefisien korelasi sebagai teknik analisis data adalah ....

a. Seorang guru ingin melihat apakah siswa dengan gaya belajar visual, auditori, dan kinestetik memiliki prestasi belajar matematika yang berbeda.

b. Seorang guru ingin memprediksi nilai ujian akhir matematika siswa dengan menggunakan nilai kemampuan pemecahan masalah, kemampuan berpikir kritis, dan kemampuan pemahaman konsep siswa.

c. Seorang guru ingin melihat apakah semakin tinggi kemampuan komunikasi matematis siswa maka semakin tinggi pula kemampuan pemecahan masalahnya.

d. Seorang guru ingin melihat apakah gaya belajar siswa (visual, auditori, dan kinestetik) dan metode mengajar (ceramah dan diskusi) berpengaruh terhadap prestasi belajar siswa.

e. Tidak ada kasus yang dapat dianalisis dengan menggunakan koefisien korelasi.

Soal 7 seharusnya tergolong mudah tetapi ternyata tidak banyak yang mampu menjawab benar. Semua pilihan jawaban merata dipilih mahasiswa. Pilihan jawaban yang benar adalah $\mathrm{C}$ yang dipilih sebanyak 12 mahasiswa. Untuk pilihan jawaban A dimana seharusnya termasuk penelitian anava satu jalan, sebanyak 8 mahasiswa memilihnya dengan alasan bahwa penelitian tersebut tidak meneliti hubungan sebab akibat. Kemungkinan konsep yang dipahami dari 8 mahasiswa tersebut adalah bahwa penelitian korelasi merupakan penelitian yang tidak berhubungan dengan sebab akibat dari variabel penelitiannya tanpa memikirkan adanya hubungan / pengaruh antara variabel penelitiannya. Untuk pilihan jawaban B dipilih tujuan sebanyak 7 mahasiswa. Kesalahan konsep yang dilakukan mahasiswa ini karena mereka mengabaikan penelitian prediksi. Penelitian yang bertujuan untuk prediksi seharusnya masuk dalam kategori penelitian regresi. Pilihan jawaban D dipilih sebanyak 3 mahasiswa, yang seharusnya termasuk dalam penelitian anava dua jalan. Ketiga mahasiswa ini terkecoh dengan kata berpengaruh. Padahal tidak semua pengaruh termasuk dalam penelitian korelasi. Sedangkan untuk pilihan jawaban E dipilih sebanyak 2 mahasiswa dengan alasan tidak ada penelitian yang hanya menggunakan teknik analisis data koefisien korelasi. Sisanya tidak dijawab mahasiswa.

Soal berikutnya, yaitu Soal 8 menguji kompetensi dasar membuat persamaan regresi yang termasuk dalam tingkatan kognitif $C_{3}$. Mahasiswa hanya menggunakan rumus untuk mencari koefisien $x$.

Soal 8. Seorang peneliti ingin memprediksi nilai $Y$ dari nilai $X$. Dari 50 pasangan data $X$ dan $Y$ diperoleh nilai-nilai sebagai berikut:

$$
\sum x=300, \quad \sum y=80, \quad \sum x^{2}=3000, \quad \sum y^{2}=250, \quad \sum x y=700 .
$$

Jika hubungan antara $X$ dan $Y$ linear dengan persamaan regresi $y=a x+b$ maka nilai a adalah .... 
a. $\frac{11}{6}$
b. $\frac{11}{60}$
c. $\frac{1}{2}$
d. $\frac{1}{20}$
e. $\frac{11}{20}$

Koefisien $x$ dapat dicari dengan menggunakan rumus yaitu

$$
a=\frac{n \sum X Y-\sum X \sum Y}{n \sum X^{2}-\left(\sum X\right)^{2}} .
$$

Namun, tidak sedikit mahasiswa yang masih salah dalam menjawab. Hanya tiga mahasiswa yang benar menjawab Soal 8 Tingkat kesukaran soal 9\% atau 0,09 yang tergolong soal sukar. Kesalahan yang paling banyak dilakukan mahasiswa adalah salah dalam menggunakan rumus. Mahasiswa justru menggunakan rumus untuk mencari nilai konstanta $b$. Selama ini persamaan regresi yang dikenal mahasiswa adalah $y=a+b x$. Mereka terkecoh dengan simbol $a$ dan $b$. Padahal di dalam soal yang diminta adalah nilai koefisien $x$. Lima belas mahasiswa salah dalam mengartikan simbol $a$ dan $b$, serta belum paham rumus yang mana yang digunakan untuk mencari koefisien $x$ maupun kontanta. Kesalahan yang lain dikarenakan mahasiswa salah dalam menghitung, sehingga sebanyak 7 orang memilih pilihan jawaban A. Sisanya yang menjawab pilihan jawaban D dikarenakan salah dalam menuliskan rumus akibatnya hasil pengerjaannya juga salah. Dari hasil analisis di atas untuk menanggulangi terjadinya kesalahan konsep, mahasiswa perlu ditekankan lagi makna koefisien $x$ dan kontanta sehingga ketika persamaan regresi dirubah definisinya, mahasiswa tidak lagi bingung dalam menggunakan rumusnya.

Analisis berikutnya mengenai soal dengan kompetensi dasar yang sama yaitu membuat persamaan regresi. Soal yang diberikan adalah Soal 9 .

Soal 9. Seorang peneliti ingin memprediksi nilai $Y$ dari nilai X. Dari 50 pasangan data X dan $Y$ diperoleh nilai-nilai sebagai berikut:

$$
\sum x=300, \quad \sum y=80, \quad \sum x^{2}=3000, \quad \sum y^{2}=250, \quad \sum x y=700 .
$$

Jika persamaan regresi antara $X$ dan $Y$ berarti maka nilai $Y$ ketika $X=30$ adalah ....

a. 11

b. 10

c. 8

d. 6

e. 3

Soal 9 termasuk dalam tingkatan ranah kognitif $C_{3}$ (aplikasi) dengan tingkat kesukaran 0,09. Soal 9 tergolong soal yang sukar. Dari soal tersebut mahasiswa diminta untuk memprediksi nilai $Y$ apabila nilai $X$ diketahui. Dalam hal ini mahasiswa harus teliti persamaan regresi yang dibuat haruslah benar agar bisa mencari nilai $Y$. Mahasiswa yang mampu menjawab benar adalah mahasiswa yang juga benar dalam membuat persamaan regresi. Sedangkan mahasiswa yang salah dalam menjawab, dikarenakan mereka juga salah dalam membuat persamaan regresi di nomer sebelumnya. Kesalahan konsep yang dilakukan mahasiswa karena terbalik dalam memasukkan nilai $a$ dan $b$, atau nilai koefisien $x$ dan konstanta.

\section{Implikasi}

Analisis kesalahan mahasiswa dalam menjawab soal UAS dapat dipakai sebagai gambaran kemampuan mahasiswa dalam materi anava, regresi, dan korelasi. Tidak hanya nilai kognitif yang bisa didapat, tetapi juga halhal apa saja yang membuat mahasiswa salah dalam menjawab soal. Selain itu, materi apa saja yang dianggap mahasiswa paling sulit juga dapat dilihat dari hasil analisis tersebut. Tingkatan ranah kognitif soal juga mempengaruhi kesalahan mahasiswa. Hal ini menjadi pertimbangan dalam melaksanakan perkuliahan. Materi yang dianggap paling sulit dapat dibuat lebih mudah dengan melihat kesulitan mahasiswa pada materi tersebut. Misalnya dalam UAS Statistika Penelitian Penelitian tahun ajaran 2016/2017 genap, mahasiswa merasa kesulitan dalam materi regresi. Maka, dalam perkuliahan semester mendatang, untuk angkatan yang lebih muda, perlu ditekankan bagaimana membuat persamaan regresi serta jenis penelitian seperti apa yang menggunakan teknik analisis data regresi. Mahasiswa perlu ditambah latihan yang berkaitan dengan dunia sehari-hari, sehingga mahasiswa lebih 
paham mengenai materi regresi. Kesulitan yang dialami mahasiswa dalam materi regresi, menyebabkan mahasiswa kesulitan dalam mengerjakan skripsinya apabila penelitiannya menggunakan teknik analisis data regresi. Bahkan sebagian besar mahasiswa untuk angkatan tersebut menghindar penelitian regresi untuk skripsinya. Sama halnya dengan materi anava. Kesalahan mahasiswa dalam materi anava adalah mahasiswa belum mampu membuat kesimpulan hasil uji anava. Sehingga, perlu dipertegas lagi dalam perkuliahan mendatang mengenai bagaimana membuat hipotesis dan bagaimana membuat kesimpulan.

\section{Kesimpulan dan Saran}

Berdasarkan hasil penelitian dan pembahasan yang telah diuraikan, maka dapat disimpulkan sebagai berikut: Kesalahan mahasiswa dalam UAS pada mata kuliah Statistika Penelitian Pendidikan paling banyak adalah kesalahan konsep dan sebagian besar pada pembahasan regresi pada kemampuan dasar membuat persamaan regresi. Kesalahan mahasiswa dominan pada soal dengan tingkatan kognitif C3 dan C4. Untuk soal mengenai analisis variansi dua jalan, kesalahan mahasiswa terletak pada membuat kesimpulan penelitian. Ketidakmampuan mahasiswa dalam membuat kesimpulan dikarenakan kesalahan konsep. Apabila hipotesis nol diterima atau ditolak mahasiswa masih kesulitan dalam membandingkan rerata. Bahkan untuk soal uji lanjut pasca analisis variansi dua jalan, apabila hipotesis antar sel ditolak maka rerata yang mana yang harus dibandingkan.

\section{Pustaka}

[1] Budiyono, 2013. Statistika Dasar Untuk Penelitian. UNS Press.

[2] Krathwohl, 2002. A revision of blooms taxonomy: An overview. Theory into Practice 41 (4).

[3] Rukmini, E., 2009. Deskripsi singkat revisi taksonomi bloom. Majalah Ilmiah Pembelajaran Volume 6 No. 2. URL https://journal.uny.ac.id/index.php/mip/article/viewFile/7132/6155

[4] Sriati, A., 1994. Kesulitan belajar matematika pada siswa sma (pengkajian diagnosa). Jurnal Pendidikan Matematika.

[5] Sulistyowati, E., 2013. Analisis kesalahan mengerjakan soal geometri pada siswa kelas v sd/mi di kota yogyakarta. Jurnal JPSD 1 (2), 1-23. 